\title{
HIV-associated multicentric castelman disease, a report of 5 cases
}

\author{
Sylvie Jonckheere*, Jean-Cyr Yombi, Anne Vincent, Leila Belkhir, Dunja Wilmes, Bernard Vandercam \\ From 17th International Symposium on HIV and Emerging Infectious Diseases (ISHEID) \\ Marseille, France. 23-25 May 2012
}

\section{Introduction}

Multicentric Castleman's disease (MCD) is a rare, nonclonal lymphoproliferative disorder characterized by constitutional symptoms, anaemia and generalised lymphadenopathy.

\section{Aim}

The present study intends to compare demographic features, clinical presentation, laboratory studies, imaging results as well as treatment regimens and out- come in our MCD patients to those of larger reported series.

\section{Method}

We reviewed the files of 930 HIV-1-infected patients from our AIDS Reference Centre. Data was collected from the operating software for the patients' medical records of our institution.

\section{Results}

We report a series of five cases of MCD among our HIV/AIDS patients' cohort. Three were of African origin. They were diagnosed after 2003, after a mean duration of 85 months of HIV-seropositivity. All presented with characteristic clinical features and laboratory findings (table 1), and all but one patient were started on HAART only a few months before or upon MCD diagnosis. Four patients were treated with chemotherapy, and one with HAART only. One patient who was given Adriamycin/Bleomycin/Vinblastin is in continuous remission after 6 years of follow-up. Two are alive, with good symptom control, regardless of the treatment they received. One recently relapsed, and one unfortunately died before completing the intended 6 -courses chemotherapy regimen.

\footnotetext{
* Correspondence: jean.yombi@uclouvain.be

Medecine Interne Infectiologie at Centre Refrence St Luc Ucl, Bruxelles, Belgium
}

\section{(O) BioMed Central}

(c) 2012 Yombi et al; licensee BioMed Central Ltd. This is an Open Access article distributed under the terms of the Creative Commons Attribution License (http://creativecommons.org/licenses/by/2.0), which permits unrestricted use, distribution, and reproduction in any medium, provided the original work is properly cited.

\section{Conclusion}

MCD is a rare, but rising issue among HIV-infected patients. The clinical and paraclinical features of our series of five patients are in keeping with those of larger reported series. Currently, treatment is mainly chemotherapy-based, but a wide variety of protocols have been used, mainly because of the lack of available evidence. New approaches such as anti-CD 20 antibodies seem highly effective, and the role of HHV-8 needs to be further investigated, as it might be an important target for future treatment.

Published: 25 May 2012

doi:10.1186/1742-4690-9-S1-P136

Cite this article as: Jonckheere et al:: HIV-associated multicentric

castelman disease, a report of 5 cases. Retrovirology 2012 9(Suppl 1):P136. and take full advantage of:

- Convenient online submission

- Thorough peer review

- No space constraints or color figure charges

- Immediate publication on acceptance

- Inclusion in PubMed, CAS, Scopus and Google Scholar

- Research which is freely available for redistribution

Submit your next manuscript to BioMed Central

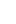

